\title{
Uuden valkuaisarvojärjestelmän toimivuus kolmirotulihasioilla
}

\author{
Soile Kyntäjä ${ }^{1)}$, Hilkka Siljander-Rasi ${ }^{1)}$, Jarkko Niemi ${ }^{2)}$ \\ ${ }^{1)}$ Luonnonvarakeskus, Vihreä teknologia, Sika- ja siipikarjaelinkeinot, 01300 Vantaa \\ ${ }^{2)}$ Luonnonvarakeskus, Talous ja yhteiskunta, 60320 Seinäjoki \\ etunimi.sukunimi@luke.fi
}

\section{Tiivistelmä}

Sikojen valkuaisarvojärjestelmä muuttui Suomessa vuoden 2014 lopussa, jolloin otettiin käyttöön standardoituihin ohutsuolisulaviin aminohappoihin perustuvat suositukset. Kokeessa selvitettiin, miten uudet aminohapposuositukset toimivat duroc -kolmirotulihasioilla ja mikä on sulavan lysiinin ja muiden aminohappojen (suhteessa lysiiniin) riittävä annostelu nelivaiheruokinnalla. Tavoitteena oli selvittää, mikä ruokintavaihtoehto on lihasikalan näkökulmasta taloudellisesti kannattavin kulloinkin tarkastelluilla hintasuhteilla.

Kokeessa oli 112 lihasikaa yksilöruokinnalla (56 imisää ja 56 leikkoa, alkupaino $29.3 \mathrm{~kg}$ ). Koeryhmiä oli neljä (R1, R2, R3 ja R4). Niiden sulavan lysiinin annostelu oli ruokintavaiheissa 1, 2, 3, ja 4: R1 1.01, 0.85, 0.80 ja 0.75 g/MJ NE (nykyinen suositus), R2 1.01, 0.85, 0.70 ja 0.65g/MJ NE, R3 $0.90,0.75,0.70$ ja $0.60 \mathrm{~g} / \mathrm{MJ}$ NE ja R4 0.90, 0.75, 0.60 ja $0.55 \mathrm{~g} / \mathrm{MJ}$ NE. Sioilla oli yksilöllinen ruokinta Spotmix -kuivaruokinta-automaateista. Siat ruokittiin rakeistetuilla täysrehuilla. Kokeessa oli kaksi perusseosta, joista koerehut sekoitettiin. Seos 1 koostui pääosin ohrasta, vehnästä ja soijarouheesta ja seos 2 ohrasta ja soijarouheesta. Rehuvaihe $1(25-55 \mathrm{~kg})$ kesti neljä viikkoa, rehuvaihe $2(55-80 \mathrm{~kg})$ kolme viikkoa, rehuvaihe $3(80-100 \mathrm{~kg})$ kaksi viikkoa ja rehuvaihe 4 teurastukseen saakka. Kokeessa mitattiin yksilökohtaisesti sikojen päiväkasvu, rehunkulutus, rehuhyötysuhde ja ruhon lihaprosentti. Koeryhmille laadittiin katetuottolaskelmat, joiden perusteella vertailtiin eri ruokintakäsittelyiden taloudellisuutta.

Rehun sulavan lysiinin vähentäminen ei vaikuttanut sikojen päiväkasvuun koko kokeen aikana (R1 ja R2 1119 g, R3 1100 g ja R4 1074 g päivässä). Aminohappojen määrän vähentäminen huononsi rehuhyötysuhdetta rehuvaiheissa 1 ja 2 . Koko kokeen aikana pienimmän aminohappotason (R4) sikojen rehuhyötysuhde (25.0 MJ NEk/kg) oli huonompi kuin kontrolliryhmässä (23.5 MJ NEk/kg). Leikkosiat pystyivät kompensoimaan suuremman syönnin kautta aminohappojen saantia rehujaksoilla 2 4 imisiin verrattuna. Pienimmällä lysiinin annostelulla (R4) ruhon lihaprosentti (60.0\%) oli pienempi kuin kontrolliryhmässä $(61.5 \%)$.

Imisillä suurimman taloudellisen ylijäämän sekä suurimman katetuoton A antoi kaikissa tapauksissa korkein aminohappotaso R1. Heikoin taloudellinen tulos puolestaan saavutettiin matalimmalla aminohappotasolla R4. Kahden keskimmäisen aminohappotason tuottojen järjestys vaihteli. Myös leikoilla paras taloudellinen tulos saavutettiin suurimmalla aminohappolisäystasolla. Sen sijaan toiseksi paras taloudellinen tulos saavutettiin matalimmalla aminohappotasolla. Leikoilla aminohappotasojen R1 ja R4 välinen tuottoero oli vain noin euro lihasikapaikkaa ja vuotta kohti. Kokonaisuutena taloudellisesti paras vaihtoehto oli korkein aminohappotaso R1.

Asiasanat: lihasika, aminohappotaso, katetuotto, taloudellinen tulos 


\section{Johdanto}

Sikojen aminohappotarpeeseen vaikuttaa sukupuoli, genotyyppi, elopaino, ruokintataso ja ympäristötekijät. Rehun valkuaisarvo määritetään rehuaineen valkuaisen ja aminohappojen sulavuuden perusteella. Suomessa sikojen uusi valkuaisarvojärjestelmä muuttui vuoden 2014 lopussa, jolloin standardoituihin ohutsuolisulaviin aminohappoihin perustuvat suositukset otettiin käyttöön. Standardoituihin aminohappoihin perustuva valkuaisarvojärjestelmä ottaa huomioon ohutsuolessa erittyvät siasta peräisin olevat aminohapot eli endogeeniset aminohapot (mm. entsyymeissä, soluissa), jota aikaisemmin käyttämämme näennäiseen ohutsuolisulavuuteen perustunut järjestelmä ei huomioinut (Stein ym. 2005).

Uudet valkuaisarvosuositukset lihasioille sisältävät standardoitujen ohutsuolisulavien lysiinin, treoniinin, metioniinin, kystiinin, tryptofaanin ja valiinin suositukset (Luke 2015). Pääosin uusien valkuaisruokintasuositusten pohjana ovat MTT:n vuonna 2001 antamat lihasikojen aminohapposuositukset, jotka on laskennallisesti muutettu uuteen järjestelmään. Rehuarvouudistustyössä on myös tehty vertailua muiden maiden aminohapposuosituksiin ja tehty suosituksiin tarkennuksia. Lihasikojen aminohappomääriä on tarkasteltu Tanskan (Tybirk ym. 2014, Ruotsin (Göransson ym. 2010), USA:n (NRC 2012) ja Iso-Britannian (BSAS 2003) ruokintasuositusten mukaan. Suomen lihasikojen aminohapposuositukset ovat suurempia verrattuna Tanskan suosituksiin. Yhtenä syynä Tanskan alempiin suosituksiin on valkuaisruokinnan taloudellisuus.

Kasvatuskokeessa selvitettiin, miten standardoituihin sulaviin aminohappoihin perustuvat suositukset toimivat duroc -kolmirotulihasioilla. Tarkoituksena oli selvittää, mikä on sulavan lysiinin ja muiden aminohappojen (suhteessa lysiiniin) riittävä annostelu Duroc- kolmirotulihasioille 4- vaiheruokinnalla. Koska teuraspainot ovat nousseet viimeisen kymmenen vuoden aikana, haluttiin erityisesti selvittää, kuinka aminohapporuokinta kannattaisi porrastaa yli $80 \mathrm{~kg}$ painoisilla lihasioilla. Lisäksi tavoitteena oli selvittää, mikä aminohappotaso on lihasikalan näkökulmasta taloudellisesti kannattavin erilaisilla hintasuhteilla.

\section{Aineisto ja menetelmät}

Kokeessa oli 112 lihasikaa yksilöruokinnalla (56 imisää ja 56 leikkoa). Koetta varten siemennettiin 20 kpl maatiais-yorkshireristeytysensikoita (Tanskan Y x (Tanskan Y x Norjan M)) DanAvel Durocseossiemenellä Jussi-Sakari Järvisen tilalla. Samasta pahnueesta tuli kokeeseen 3 - 14 porsasta. Porsaat vietiin koepaikkaan, Figen Oy:n Längelmäen testiasemalle kolmessa erässä. Porsaat jaettiin kokeeseen keskimäärin 29,3 kg painoisina (CV 15,2 \%). Tunnistusta ja ruokintaa varten jokaiselle sialle asennettiin korvalehteen transponderi. Porsaat jaettiin neljään koeryhmään, 14 imisää ja 14 leikkoa/ryhmä, yhteensä 28 sikaa/ryhmä. Imisät ja leikot kasvatettiin samoissa karsinoissa. Kussakin karsinassa oli 4-6 imisää ja 4- 6 leikkoa. Jokaisessa koekarsinassa oli 11 sikaa (kolme karsinaa/ryhmä, yhteensä 12 karsinaa). Erän 2 osalta, jossa oli kussakin koeryhmässä vain 6 sikaa, karsinoita täydennettiin koeaseman omilla porsailla. Siat olivat kolmessa eri osastossa porsaiden tulopäivän mukaan. Sikojen tavoiteteuraspaino oli $86 \mathrm{~kg}$.

Kokeessa oli neljä koeryhmää. Alkukasvatuksessa, 1. ja 2. rehuvaiheissa, rehun lysiinitasoja oli kaksi. Ryhmät 1 ja 2 sekä ryhmät 3 ja 4 olivat samalla aminohappotasolla $(1,01 \mathrm{~g}$ vs. $0,90 \mathrm{~g}$ sulavaa lysiiniä/MJ $\mathrm{NE}_{\mathrm{k}}$ vaiheessa $1 \mathrm{ja} 0,85 \mathrm{~g}$ vs. $0,75 \mathrm{~g}$ sulavaa lysiiniä/MJ $\mathrm{NE}_{\mathrm{k}}$ vaiheessa 2 ). Kolmannessa rehuvaiheessa sulavan lysiinin tasoja oli kolme: $0,8 \mathrm{~g}$ (ryhmä 1), $0,7 \mathrm{~g}$ (ryhmät 2 ja 3) ja 0,6 g/MJ NE $\mathrm{k}_{\mathrm{k}}$ (ryhmä 4). Yli $100 \mathrm{~kg}$ painossa, 4. rehuvaiheessa, jokaisella ryhmällä oli erilainen sulavan lysiinin taso (7,0 g, 6,0 g, 5,6 g ja 5,3 g/MJ NE $\mathrm{k}_{\mathrm{k}}$ ryhmissä 1 - 4). Muiden välttämättömien aminohappojen (treoniini, metioniini+kystiini, valiini ja tryptofaani) suhde lysiiniin pidettiin suositusten mukaisena.

Sioilla oli yksilöllinen ruokinta Spotmix -kuivaruokinta-automaateista (Schauer Agrotronic $\mathrm{GmbH}$, Itävalta), joissa oli yksi ruokintapaikka karsinaa kohti. Kaikki siat ruokittiin rakeistetuilla täysrehuilla. Kokeessa oli kaksi perusseosta (rehu 1 ja rehu 2). Rehu 1 koostui pääosin ohrasta, vehnästä ja soijarouheesta ja rehu 2 ohrasta ja soijarouheesta. Perusseosten standardoidun sulavan lysiinin laskennalliset määrät olivat $1,01 \mathrm{ja} 0,55 \mathrm{~g} / \mathrm{MJ} \mathrm{NE}_{\mathrm{k}}$. Muut koerehut sekoitettiin perusseoksista. Seosten kivennäis- ja vitamiinipitoisuudet olivat vähintään ruokintasuositusten mukaiset. Koko kokeen rehut tehtiin yhdellä valmistuskerralla Suomen Rehu Oy:ssä. Perusseokset valmistettiin noin 1 kk ennen kokeen alkua, ja lopulliset rehuseokset optimoitiin niiden analyysitulosten perusteella. Koeryhmien 3 
ja 4 ensimmäisen rehuvaiheen seoksiin lisättiin myös kivennäisseosta (Pekoni sikakivennäinen) ki-vennäisruokintasuosituksen täyttymiseksi.

Alkukasvatuksen rehuvaihe $1(25-55 \mathrm{~kg})$ kesti neljä viikkoa, josta viimeinen viikko syötettiin 1 ja 2 vaiheen rehuja suhteessa 50:50. Rehuvaihe $2(55-80 \mathrm{~kg})$ kesti kolme viikkoa, josta viimeisellä viikolla vaiheiden 2 ja 3 rehuja syötettiin suhteessa 50:50. Loppukasvatusvaihe jaettiin kahteen osaan niin, että vaihe 3 kesti kaksi viikkoa ja 4 rehuvaihe teurastukseen saakka.

\section{Mittaukset ja analyysit}

Siat punnittiin kokeen alussa sekä kasvatusviikoilla 2, 4, 6 ja tästä lähtien joka viikko teurastukseen saakka. Siat teurastettiin Atrian Saarioisten teurastamolla Jyväskylässä. Teurastamolla määritettiin Hennessy- lihaprosentti kaikilta sioilta.

Perusrehuseoksista otettiin näytteet valmistuksen yhteydessä ja ne analysoitiin ennen kokeen alkamista. Näytteistä analysoitiin kuiva-aine $\left(105{ }^{\circ} \mathrm{C}, 20 \mathrm{~h}\right)$. Tuhka, raakavalkuainen, raakarasva ja raakakuitu määritettiin standardimenetelmin (AOAC 1990). Valkuaismääritys tehtiin Leco FP 428 typpianalysaattorilla (Leco Corp., St Joseph; MI 49085; USA). Aminohappokoostumus määritettiin European commission (1998) menetelmän mukaan.

Tulosten tilastollinen analysointi tehtiin SAS-ohjelmiston MIXED- proseduurilla. Tilastollisessa mallissa oli kiinteinä tekijöinä ruokintaryhmän ja sukupuolen vaikutus ja niiden yhdysvaikutus sekä satunnaistekijänä kasvatuserän vaikutus. Teurastulosten (teuraspaino, teurastappio, lihaprosentti) analyysissä ei ollut mukana satunnaistekijää. Ruokintaryhmien välisiä eroja testattiin Dunnettin post hoc -testillä, joka vertaa jokaisen koeryhmän tulosta pareittain kontrolliryhmän tulokseen (ryhmä 1). Rehuvaiheiden 1 ja 2 tulosten analysoinnissa koeryhmien 1 ja 2 sekä 3 ja 4 tulokset yhdistettiin.

Eri ruokintavaihtoehtojen taloudellisuuden selvittämiseksi kullekin käsittelylle laskettiin kate-tuotto A ja taloudellinen ylijäämä. Laskelmat vakioitiin keskipainoiselle koesialle $(86.3 \mathrm{~kg}$ teuraspai-no) tai lihasikapaikkaa ja vuotta kohti viikon pesutauko kasvatuserien välissä. Laskelmissa otettiin huomioon koesiat, joille oli mitattu kaikki tuotantotulokset sekä lihaprosentti. Lihan tilityshinnat saa-tiin teurastamolta ruhokohtaisesti. Lihan keskihinta oli $1.52 € / \mathrm{kg}$. Rehujen hinnan perustuivat koetta varten hankittuihin rehuihin, joista koerehuseokset sekoitettiin. Muina tuottoina huomioitiin eläinten hyvinvointituki ja kustannuksina porsaiden oston, muiden muuttuvien kustannusten sekä työn, pää-oman, rakennusten, koneiden ja laitteiden sekä vakuutuksen ja kunnossapidon kustannukset alkuvuo-den 2015 kustannustason mukaisesti. Laskelmille tehtiin herkkyysanalyysi toistamalla ne $20 \%$ edellä mainittua korkeammalla ja/tai pienemmällä rehun tai lihan hinnalla. Rehun osalta tarkasteltiin myös $40 \%$ alempaa hintaa. Tulokset raportoitiin ruokintakäsittelyittäin ja sukupuolittain. Lopuksi tehtiin tilastollinen analyysi lineaarisella mallilla (Matlab econometrics toolbox, LeSage, 2005), jolla testat-tiin vaikutusten merkitsevyys.

\section{Tulokset ja tulosten tarkastelu \\ Rehujen kemiallinen koostumus}

Analyysien mukaan perusrehut 1 ja 2 sekä koeseokset, jotka sekoitettiin perusseoksista, olivat pääosin suunnitellun mukaisia. Rehun 1 raakavalkuainen oli suunnitellusta tasosta $4 \%$ pienempi ja koerehun 2 raakavalkuainen oli $5 \%$ suunniteltua tasoa pienempi. Rehun 1 lysiinipitoisuus oli $4 \%$ suunniteltua pienempi, mutta rehun 2 lysiinipitoisuus oli $6 \%$ suunniteltua tasoa suurempi.

Kalsiumin osalta rehun 1 pitoisuus oli $20 \%$ suunniteltua suurempi ja rehun 2 kalsiumpitoisuus oli suunnitellun mukainen. Sikojen kasvu

Kokeesta jouduttiin poistamaan terveysongelmien takia yhdeksän sikaa $(8,0 \%)$. Siat, jotka on poistettu kokeesta tietyn rehuvaiheen jälkeen, eivät ole mukana koko kasvatuskauden tuloksissa. Koko kasvatuskauden tuotantotulokset saatiin kaikkiaan 103 sialta. Siat kasvoivat koko kokeen ajan erittäin hyvin. Koko kasvatusajalla päiväkasvu oli keskimäärin 1115 g/d (vaihtelu 825 - 1427 g/d, CV 11,1 $\%)$. Aminohappojen annostelulla ei ollut vaikutusta sikojen päiväkasvuun eri koeryhmien välillä (Taulukko 1.). Imisien ja leikkojen päiväkasvussa ei ollut eroa 1. rehuvaiheessa, mutta muissa rehuvaiheissa ja koko kokeessa leikot kasvoivat imisiä paremmin $(\mathrm{p}<0,01)$. Leikkojen keskimääräinen kasvatusaika oli noin 4 päivää lyhyempi kuin imisien $(p<0,05)$. Merkitseviä yhdysvaikutuksia ei havaittu ruokinnan ja sukupuolen välillä.

\section{Sikojen rehunkäyttö}

Koesiat söivät kokeessa keskimäärin $202 \mathrm{~kg}$ rehun kuiva-ainetta (ka), mikä on $230 \mathrm{~kg}$ ilmakuivaa rehua ja $2185 \mathrm{MJ} \mathrm{NE}_{\mathrm{k}}$ koko kokeen aikana. Kuiva-aineen syönnin vaihteluväli oli 163 - $263 \mathrm{~kg}$ ka (CV 9,57 \%). Päiväkohtainen rehunkulutus koko kokeen aikana oli 2,47 kg ka/d (vaihteluväli 1,83 - 
$2,97 \mathrm{~kg} \mathrm{ka} / \mathrm{d})$. Rehun aminohappotaso ei vaikuttanut sikojen kokonaisrehunkulutukseen tai rehun päiväsyönteihin eri rehuvaiheissa tai koko kokeen aikana ( $\mathrm{kg} k \mathrm{ka}, \mathrm{MJ} \mathrm{NE}_{\mathrm{k}}$ ) (Taulukko1.). Leikkojen ja imisien rehun kokonaiskulutuksessa ( $\mathrm{kg} \mathrm{ka}, \mathrm{MJ} \mathrm{NE}$ ) ei ollut eroa rehuvaiheissa $1 \mathrm{ja} 4$. Rehuvaiheissa 2 ja 3 sekä koko kokeen aikana leikkojen rehun kokonaiskulutus oli suurempi kuin imisien ( $\mathrm{p}<0,001)$. Rehunkulutuksessa ei havaittu yhdysvaikutuksia sukupuolen ja ruokinnan välillä.

Alkukasvatuksessa sikojen rehun syöntikyky ei riittänyt nostamaan aminohappojen saantia suositusten mukaiseksi ryhmissä 3 ja 4 . Ruokintavaiheessa 3 siat pystyivät kompensoimaan rehun syönnin avulla 10 prosenttia pienemmän rehun lysiinimäärän. Kokeessa ruokintavaihe 4 jäi sioilla lyhyeksi, koska suuri osa eläimistä saavutti teuraspainon aiemmin. Jäljelle jääneet siat saavuttivat suositusten mukaisen aminohappojen saannin.

Sikojen rehuhyötysuhde koko kokeessa oli keskimäärin $2,53 \mathrm{~kg}$ rehua/kasvukg $(2,23 \mathrm{~kg}$ $\mathrm{ka} / \mathrm{kasvukg}$ tai 24,0 MJ NEk/kasvukg). Vaihteluväli koko kokeen rehuhyötysuhteessa, $\mathrm{kg}$ rehua/kasvukg oli 2,18 - 2,86 (CV 5,65\%). Verrattaessa ryhmiä pareittain kontrolliin (R1), rehuvaiheessa 1 ryhmien 3 ja 4 sikojen rehuhyötysuhde oli huonompi. Vastaavasti rehuvaiheessa 2 vain ryhmän 4 rehuhyötysuhde oli huonompi kuin kontrolliryhmässä. Rehuvaiheessa 3 ja 4 ei ollut eroja rehuhyötysuhteessa ryhmien välillä. Koko kokeen aikana ryhmän 4 sikojen rehuhyötysuhde oli merkitsevästi huonompi kuin kontrolliryhmässä $(\mathrm{p}<0,001)$. Koko kokeen aikana imisien ja leikkojen rehuhyötysuhteessa ei ollut eroa. Rehuvaiheissa 1 ja 4 havaittiin yhdysvaikutus ruokinnan ja sukupuolen välillä rehuhyötysuhteessa.

\section{Sikojen teuraslaatu}

Yksilölliset teurastulokset saatiin kokeessa 94 sialta. Toteutunut teuraspaino 86,3 kg (vaihteluväli 74,0 - 95,5, CV 5,36 \%). Eri ruokintaryhmien välillä ei ollut eroja teuraspainossa. Myös teurastappioprosentti oli samanlainen eri ryhmissä. Sikojen koko ruhon lihaprosentit olivat hyviä. Keskimääräinen ruhon lihaprosentti kokeessa oli 60,9 (vaihteluväli 54 - 65, CV 3,30 \%). Ruhoista 21,3\%:1la lihaprosentti oli alle 59. Ryhmässä 4 ruhon lihaprosentti oli pienempi kontrolliryhmään verrattuna $(p<0,05)$ (Taulukko 1.). Leikoilla oli pienempi ruhon lihaprosentti kuin imisillä $(\mathrm{p}<0,001)$. Yhdysvaikutuksia ruokinnan ja sukupuolen välillä ei teurastuloksissa havaittu.

\section{Sikatuotannon taloudellinen ylijäämä}

Taulukossa 2 on esitetty ruokintavaihtoehtojen taloudellinen tulos kulloinkin käytetyillä hintasuhteilla ruokintavaihtoehtoon R1 verrattuna. Baseline-vaihtoehto kuvaa kokeessa toteutuneita hintasuhteita. Sekä suurimman taloudellisen ylijäämän että suurimman katetuoton A antoi kaikissa tapauksissa korkein aminohappotaso R1. Kokeen keskipainoiselle lihasialle (86,3 $\mathrm{kg}$ teuraspaino) vakioitu taloudellinen ylijäämä ruokintaryhmällä R1 oli imisillä -11,26 €/imisä (SD 7,62) ja leikoilla -10,91 €/leikko (SD 5,41). Lihasikapaikkaa ja vuotta kohti laskettu taloudellinen ylijäämä ruokintaryhmällä R1 oli imisillä $-43,56 € /$ imisä (SD 27,80) ja leikoilla -46,96€/leikko (SD 18,46).

Imisillä heikoin taloudellinen tulos saatiin pienimmällä aminohapotasolla R4. Leikoilla toiseksi paras taloudellinen tulos saavutettiin pienimmällä aminohappotasolla. Leikoilla aminohappotasojen R1 ja R4 välinen tuottoero oli vain noin euro lihasikapaikkaa ja vuotta kohti. Tilastollisen analyysin perusteella teuraspaino ja porsaan paino vaikuttavat erittäin merkitsevästi katetuottoon. Teuraspainon vaikutus katetuottoon oli 3-4 $€ / \mathrm{kg}$ ruhopainoa. Sen sijaan ruokintakäsittelyiden p-arvot ovat suuria. Imisillä aminohappotasojen R1 ja R4 välinen ero katetuotossa A oli melkein merkitsevä ( $\mathrm{p}=0.078)$, kun teuraspainoa ei otettu huomioon.

Herkkyysanalyysin mukaan siankasvatuksen taloudellinen ylijäämä nousi, kun lihan hinta nousi tai rehun hinta laski. Suurimman taloudellisen tuoton antanut aminohappotaso oli kuitenkin sama (R1) lähes kaikissa tarkastelluissa vaihtoehdoissa. Ainoastaan rehun hinnan noustessa $20 \%$ matalin aminohappotaso R4 antoi suuremman taloudellisen ylijäämän kuin korkein aminohappotaso R1, ja silloinkin tulos vain tarkasteltaessa lihasikapaikkakohtaisia tuloksia leikkojen osalta. Myös lihan hinnan laskiessa (ceteris paribus) ruokinnan R4 kannattavuus parani R1:en verrattuna. 
Taulukko 1. Sikojen kasvu, rehunkäyttö ja teuraslaatu eri koeryhmissä.

\begin{tabular}{|c|c|c|c|c|c|c|}
\hline & R 1 & $\mathrm{R} 2$ & R 3 & $\mathrm{R} 4$ & SEM & p-arvo \\
\hline \multicolumn{7}{|l|}{ Päiväkasvu, $g$} \\
\hline $25-55 \mathrm{~kg}$ & 947 & 939 & 892 & 904 & 60,0 & \\
\hline $55-80 \mathrm{~kg}$ & 1185 & 1175 & 1126 & 1092 & 56,9 & \\
\hline $80-100 \mathrm{~kg}$ & 1234 & 1258 & 1224 & 1185 & 47,1 & \\
\hline $100 \mathrm{~kg}$ - teur. & 1176 & 1228 & 1277 & 1200 & 64,1 & \\
\hline Koko kokeen aikana & 1119 & 1119 & 1100 & 1074 & 42,5 & \\
\hline$\underline{\text { Kasvatusaika, d }}$ & 83,3 & 80,6 & 84,2 & 84,8 & 3,41 & \\
\hline \multicolumn{7}{|l|}{$\underline{\text { Rehunkulutus, kg ka }}$} \\
\hline Rehuvaihe 1 & 44,3 & 45,6 & 44,0 & 44,7 & 2,47 & \\
\hline Rehuvaihe 2 & 50,8 & 51,5 & 50,2 & 51,1 & 2,04 & \\
\hline Rehuvaihe 3 & 41,6 & 43,5 & 42,3 & 42,0 & 1,40 & \\
\hline Rehuvaihe 4 & 67,8 & 59,6 & 68,5 & 76,4 & 8,01 & \\
\hline yhteensä & 199,7 & 197,9 & 205,2 & 208,0 & 4,50 & \\
\hline \multicolumn{7}{|c|}{$\underline{\text { Rehuhyötysuhde, kg ka/kasvukg }}$} \\
\hline Rehuvaihe 1 & $1,68^{\mathrm{a}}$ & $1,76^{\mathrm{a}}$ & $1,79^{\mathrm{b}}$ & $1,77^{\mathrm{b}}$ & 0,06 & $* *$ \\
\hline Rehuvaihe 2 & $2,05^{\mathrm{a}}$ & $2,10^{\mathrm{a}}$ & $2,13^{\mathrm{a}}$ & $2,23^{\mathrm{c}}$ & 0,05 & $* * *$ \\
\hline Rehuvaihe 3 & 2,41 & 2,47 & 2,49 & 2,56 & 0,10 & \\
\hline Rehuvaihe 4 & 2,90 & 2,88 & 2,67 & 2,85 & 0,11 & \\
\hline Koko koe & $2,17^{\mathrm{a}}$ & $2,22^{\mathrm{a}}$ & $2,24^{\mathrm{a}}$ & $2,31^{\mathrm{c}}$ & 0,04 & $* * *$ \\
\hline \multicolumn{7}{|l|}{ Teurasominaisuudet } \\
\hline Koko koe & $23,5^{\mathrm{a}}$ & $24,0^{\mathrm{a}}$ & $24,2^{\mathrm{a}}$ & $25,0^{\mathrm{c}}$ & 0,39 & $* * *$ \\
\hline Teuraspaino, kg & 87,9 & 84,8 & 86,8 & 85,7 & 0,94 & \\
\hline Liha-\% & $61,5^{\mathrm{a}}$ & $61,0^{\mathrm{a}}$ & $61,1^{\mathrm{a}}$ & $60,0^{\mathrm{b}}$ & 0,36 & $* *$ \\
\hline Teurastappio-\% & 27,7 & 28,1 & 28,4 & 28,0 & 0,35 & \\
\hline
\end{tabular}

Taulukko 2. Kokeessa kasvatettujen imisien ja leikkojen taloudellinen ylijäämä (€/lihasikapaikka/vuosi) kokeessa toteutuneilla hintasuhteilla (baseline) sekä vaihtoehtoisilla hintasuhteilla eri aminohappotasoilla ruokintaryhmään R1 verrattuna.

\begin{tabular}{lccccc}
\hline Ryhmä & Baseline & $\begin{array}{c}\text { Liha }+20 \\
\%\end{array}$ & $\begin{array}{c}\text { Rehu }+20 \\
\%\end{array}$ & $\begin{array}{c}\text { Rehu }-20 \\
\%\end{array}$ & $\begin{array}{c}\text { Rehu }-40 \\
\%\end{array}$ \\
\hline Imisä, R2 & -8.3 & -9.9 & -7.5 & -12.2 & -12.3 \\
Imisä, R3 & -4 & -8.1 & -2.2 & -12.8 & -12.1 \\
Imisä, R4 & -20.4 & -28.2 & -18.6 & -31.3 & -29.7 \\
Leikko, R2 & -5.9 & -4.4 & -7.2 & -7.7 & -7.4 \\
Leikko, R3 & -9.7 & -17.3 & -7.8 & -18.9 & -17.2 \\
Leikko, R4 & -1 & -7.1 & 1.8 & -13.6 & -12.8 \\
\hline
\end{tabular}

Johtopäätökset

Tuotantotulosten perusteella kokeessa käytettyjen kolmiroturisteytyssikojen tuotantopotentiaali oli hyvin korkea. Kokeen tekninen toteutus Figen Oy:n testiasemalla sujui hyvin, mutta $8 \%$ sioista poistui kokeesta ennen sen päättymistä. Siat sopeutuivat hyvin automaattiruokintaan. Myös teurastiedot jäivät puuttumaan muutamalta sialta.

Rehun sulavan lysiinin vähentäminen ei vaikuttanut sikojen kasvutuloksiin koko koejaksolla. Sen sijaan rehuhyötysuhteeseen aminohappojen määrän vähentäminen vaikutti negatiivisesti lähes kaikilla koejaksoilla. Koko kokeen tuloksissa kuitenkin vain pienimmän aminohappotason (R4) sikojen rehuhyötysuhde oli huonompi kuin kontrolliryhmän sikojen. Leikkosiat pystyivät kokeen lopussa 
kompensoimaan suuremman syönnin kautta aminohappojen saantia alemman lysiinin ryhmissä paremmin kuin imisät.

Sikojen punaisen lihan tuottokyky oli korkea. Rehun lysiinipitoisuuden pienentäminen pienensi kuitenkin alimmalla lysiinin annostelulla (R4) ruhon lihaprosenttia kontrolliryhmään verrattuna.

Tuotantotulosten perusteella koko kasvatuskauden jatkunut niukahko aminohappojen annostelu suosituksiin verrattuna jäi kontrolliryhmää huonommaksi, mutta kaksi lievästi pienennettyä aminohappotasoa olivat verrattavissa suositusten mukaiseen tulokseen. Kokeessa käytettiin tasalaatuisia vilja-soijaseoksia, mutta tiloilla viljan ja muiden rehujen koostumuksen vaihdellessa voisi olla turvallista pyrkiä lähelle suositusten mukaista ruokintaa. Tuloksista ei selviä, kuinka paljon siat olisivat hyötyneet suosituksia suuremmasta aminohappojen annostelusta.

Kokeen tulokset ovat samansuuntaisia kuin Zhangin ym. (2011) kokeiden tulokset, joissa tutkittiin standardoidun lysiinin ja energian suhdetta eri tasoilla. Myös de la Llata ym. (2007) ja Main ym. (2008) totesivat tutkimuksessaan, että kasvutulokset paranevat lineaarisesti kun lysiini:energiasuhde nousee.

Taloudellisen arvioinnin tulokset viittaavat siihen, että imisillä ja leikoilla kannattaa pyrkiä runsaaseen valkuaisruokintaan. Taloudellisesti optimaalinen aminohappotaso saattaisi olla jopa tasoa R1 korkeampi, sillä katetuotto nousi korkeampaan aminohappotasoon siirryttäessä. Koeaineiston perusteella korkeamman aminohappotason taloudellisuutta ei kuitenkaan voida vahvistaa. Tulosten perusteella niukan aminohapporuokinnan kannattavuus paranee markkinasuhdanteen heikentyessä.

\section{Kirjallisuus}

AOAC. 1990. Official Methods of Analysis. Association of Official Analytical Chemists. Inc. Arlington. VA. 1298 p. ISBN 0-935584-42-0.

BSAS. British Society of Animal Science. 2003. Nutrient requirement standards for pigs. (Authors: Whittemore. C.T. Hazzledine. M.J. and Close. W.H.). BSAS. Penicuik.

European Commission. 1998. Commission Directive 98/64/EC. Community Methods of Analysis for the determination of amino acids. crude oils and fats. and olaquindox in feeding stuffs and amending Directive 71/393/EEC. Official Journal L 257. 19/09/1998 p. 14-28.

Göransson. L.. Lindberg. J.E. and Borkling. J. 2010. Näringsrekommendationer. Aminosyrer. Institutionen för husdjurens utfodning ach vård. 5 p. Available in internet at: http://www.slu.se/Documents/externwebben/vhfak/husdjurens-utfodring-och-

vard/Verktyg/Fodermedel\%20och\%20n\%c3\%a4ringsrek\%20till\%20gris/N\%c3\%a4ringsrekommendationer/Nar ingsrekommendation_Aminosyror_2010_2.pdf

LeSage. J.P. 2005. Econometrics Toolbox. http://www.spatial-econometrics.com. Downloaded March 2006.

de la Llata, M., Dritz, S.,Tokach, M., Goodband, R. and Nelssen, J. 2007. Effects of increasing lysine to calorie ratio and added fat for growing-finishing pigs reared in a commercial environment: I. growth performance and carcass characteristics. Professional Animal Scientist, 23: 417-428.

Luh Huang. C.-Y. and E.E. Schulte. 1985. Digestion of plant tissue for analysis by ICP emission spectrometry. Communications in soil science and plant analysis 16: 943-958.

Luke. 2015. Rehutaulukot ja ruokintasuositukset. Märehtijät - Siat - Siipikarja - hevoset. Luonnonvara- ja Biotaloudentutkimus 40/2015, $80 \mathrm{p}$.

Main, R., Dritz, S., Tokach, M., Goodband, R. and Nelssen, J. 2008. Determining an optimum lysine:calorie ratio for barrows and gilts in a commercial finishing facility. Journal of Animal Science 86:2190-2207.

NRC. 2012. Nutrient requirements of swine. Eleventh Revised edition. National Research Council (US). Committee of Nutrient Requirements of Swine. Washington. 400 p.

Stein, H. H., Pedersen, C., Wirt, A.R. and Bohlke, R. A.. 2005. Additivity of values for apparent and standardized ileal digestibility of AA in mixed diets fed to growing pigs. J. Anim. Sci.83:2387-2395.

Tybirk. P. Sloth. N.M. and Jorgensen. L. 2014. Nutrient Requirement Standards. Videcenter for Svineproduction. $11 \mathrm{p}$.

Zhang, G., Yi, X., Chu, L., Lu, N., Htoo, J. and Qiao, S. 2011. Effects of dietary net energy density and standardized ileal digestible lysine:net energy ratio on the performance and carcass characteristic of growingfinishing pigs fed low crude protein supplemented with crystalline amino acids diets. Agricultural Sciences in China 10:602-610. 